\begin{tabular}{|} 
Ambiente \& Água - An Interdisciplinary Journal of Applied Science \\
ISSN 1980-993X - doi:10.4136/1980-993X \\
www.ambi-agua.net \\
E-mail: ambi.agua@gmail.com
\end{tabular}

\title{
Defining environmental conservation levels considering anthropic activity in the Uberaba River Basin protected area
}

\author{
ARTICLES doi:10.4136/ambi-agua.2279
}

Received: 15 May 2018; Accepted: 01 Nov. 2018

\author{
Allita Rezende dos Santos ${ }^{1 *}$; Renato Carneiro Fernandes da Silva ${ }^{2}$; \\ Leonardo Campos de Assis ${ }^{2}$; Frederico Fábio Mauad ${ }^{1}$ (D) \\ ${ }^{1}$ Escola de Engenharia de São Carlos da Universidade de São Paulo (EESC-USP), São Carlos, SP, Brasil \\ Centro de Recursos Hídricos e Estudos Ambientais (CRHEA). E-mail: allita.santos@gmail.com, \\ mauadffm@sc.usp.br \\ ${ }^{2}$ Universidade de Uberaba (UNIUBE), Uberaba, MG, Brasil \\ Laboratório de Geoprocessamento.E-mail: renato.carneirofs@hotmail.com, leonardo.assis@uniube.br \\ *Corresponding author
}

\begin{abstract}
Environmental conservation of river basins in general is essential for water quality and ecological maintenance, especially in spring areas. Despite being characterized as a Conservation Unit (CU) of Sustainable Use (SU), the Uberaba River Basin highlands are highly influenced by anthropic activities. The aim of this study was to determine different levels of conservation required to maintain environmental quality. The Multicriteria evaluation method was used as follows: i) applied fuzzy membership functions to standardization of the continuous data values or reclassified when categorical criteria; (ii) established criteria ranking through the pairwise relative importance comparison approach by the Analytical Hierarchy Process (AHP) method and; (iii) performed Weighted Linear Combination (WLC). The selected criteria were maps of the: land cover obtained by supervised classification of a satellite image, with $94 \%$ of Kappa Index of Agreement (KIA); soil types, slope; distances from rivers, roads; railways and urban limits. A main outcome of the criteria evaluated is a map of continuous data values expressing distinct levels of environmental conservation requirements. The highest values that express the need for conservation occurred near the ridgetop, corresponding to forest land cover, high slope and hydromorphic soils. The lowest values were observed in the peri-urban areas, in more stable soil and soil cover with a higher degree of occupation. It is concluded that the resulting map can assist in decision-making regarding proper management of the area, to achieve sustainability in the application of occupation policies.
\end{abstract}

Keywords: environmental degradation, multicriteria, weights comparison.

\section{Definição dos níveis de conservação ambiental considerando a ocupação antrópica na área protegida da bacia hidrográfica do rio Uberaba}

\section{RESUMO}

A conservação ambiental das bacias hidrográficas em geral é essencial para a qualidade da água e manutenção ecológica, especialmente nas áreas de nascentes. Apesar de se caracterizar como uma Unidade de Conservação de Uso Sustentável, as terras altas da bacia do rio Uberaba 
são altamente influenciadas por atividades antrópicas. O objetivo deste estudo foi determinar diferentes níveis de conservação necessários para a manutenção da qualidade ambiental. Utilizou-se o método Avaliação Multicritérios segundo os passos: i) aplicação de funções de pertinência fuzzy para padronização dos valores de dados contínuos ou reclassificação quando critérios categóricos; ii) hierarquização dos critérios por comparação da importância relativa a partir do método Processo Analítico Hierárquico e; iii) realização da Combinação Linear Ponderada. Os critérios selecionados foram mapas de: cobertura do solo obtido por classificação supervisionada de imagem de satélite, com 94\% de índice estatístico Kappa, tipos de solo, declividade, distâncias a partir dos rios, estradas, ferrovia e limites urbanos. Um dos principais resultados dos critérios avaliados é um mapa de valores de dados contínuos que expressam níveis distintos de requisitos de conservação ambiental. Os maiores valores que expressam a necessidade de conservação ocorreram próximos ao divisor de águas, correspondendo a vegetação nativa, alta declividade e solos hidromórficos. Os menores valores foram observados nas áreas periurbanas, em solos mais estáveis e cobertura do solo com maior grau de ocupação. Conclui-se que o mapa resultante pode auxiliar na tomada de decisão quanto ao manejo adequado da área, visando a sustentabilidade na aplicação de políticas de ocupação.

Palavras-chave: comparação pareada, degradação ambiental, multicritérios.

\section{INTRODUCTION}

Human activities generate a set of impacts on aquatic ecosystems as a result of population, industry and world economy growth (Tundisi et al., 2003). This deterioration is related to growth and agricultural diversification, as well as the increase in urbanization and intensification of activities in the basin. The excessive use of the soil and water, deforestation and non-sustainable management, may be relate to water level decline, toxic contamination, eutrophication, acidification and material increase in suspension inside the water bodies. (Tundisi, 2005). This information reflects some of the complex interactions that are present in the environment.

The natural environment as a complex system must be analyzed under a multivariate perspective. In addition, sustainable management of natural resources also depends on the environmental conservation state of a river basin (Tundisi and Matsumura-Tundisi, 2014), since each unit has physical, ecological, economic and hydrological characteristics. In this sense, the studies related to environmental conservation should include, in addition to bio-geophysical characteristics of a system, other factors such as the influence of human activities on aquatic environments (Mishra and Rai, 2016). From this, the concept of environmental conservation approached in this study includes the main set of factors that promote, among other impacts, soil erosion. These factors are vegetative cover, slope, soil cover and soil types, allied to water bodies and road systems (Zhang et al., 2010; Vettorazzi and Valente, 2016).

The integrated vision can promote a good understanding of the negative impacts occurring in water bodies, considering the distinct nature of the factors that influence the environment. Thus, upon assigning values to the criteria of an environmental assessment, the alternatives that optimize the decision are prioritized (Franco et al., 2013). The criteria are standardized by fuzzy pertinence function, hierarchized by comparison in pairs and weighted according to the study purpose, in order to support the decision-making process of a Multi-criteria Evaluation (MCE) (Eastman, 2012; Franco et al., 2013; Montgomery et al., 2016).

Some studies with methodology similar to this identified priority areas for forest restoration (Vettorazzi and Valente, 2016), and for environmental conservation in relation to the erosion risk (Zhang et al., 2010), or evaluating suitable areas for agriculture (Montgomery et al., 2016); but studies considering the delimitation of protected areas by environmental 
legislation, e.g., conservation units for sustainable use in Brazil, should also be discussed and compared, including with other countries.

Considering the above, the environmental assessments with interleaved goals can be studied from tools such as Geographic Information Systems (GIS). Thus, the objective of this study is the definition of environmental conservation areas through suitability levels of natural fragility, considering anthropic occupation in the Environmental Protection Area (EPA) of the Uberaba River Basin (URB). In this way, the present study can contribute to sustainable management by public agencies and to decision making applied in spatial analysis for environmental conservation studies.

\section{MATERIALS AND METHODS}

\subsection{Study area}

The study area corresponds to the EPA of the Uberaba River Basin (EPA-URB) (Figure 1). It is in South America and the southern part of Brazil, Minas Gerais state and Uberaba city. With a population estimated at almost 330 thousand in the year 2017 (IBGE, 2017), the city is one of eight major cities of the state, and from a geo-economics standpoint has highly strategic viability due to its location approximately $500 \mathrm{~km}$ from the main capitals, in the center of one of the country's most important consumer markets (Uberaba, 2012).
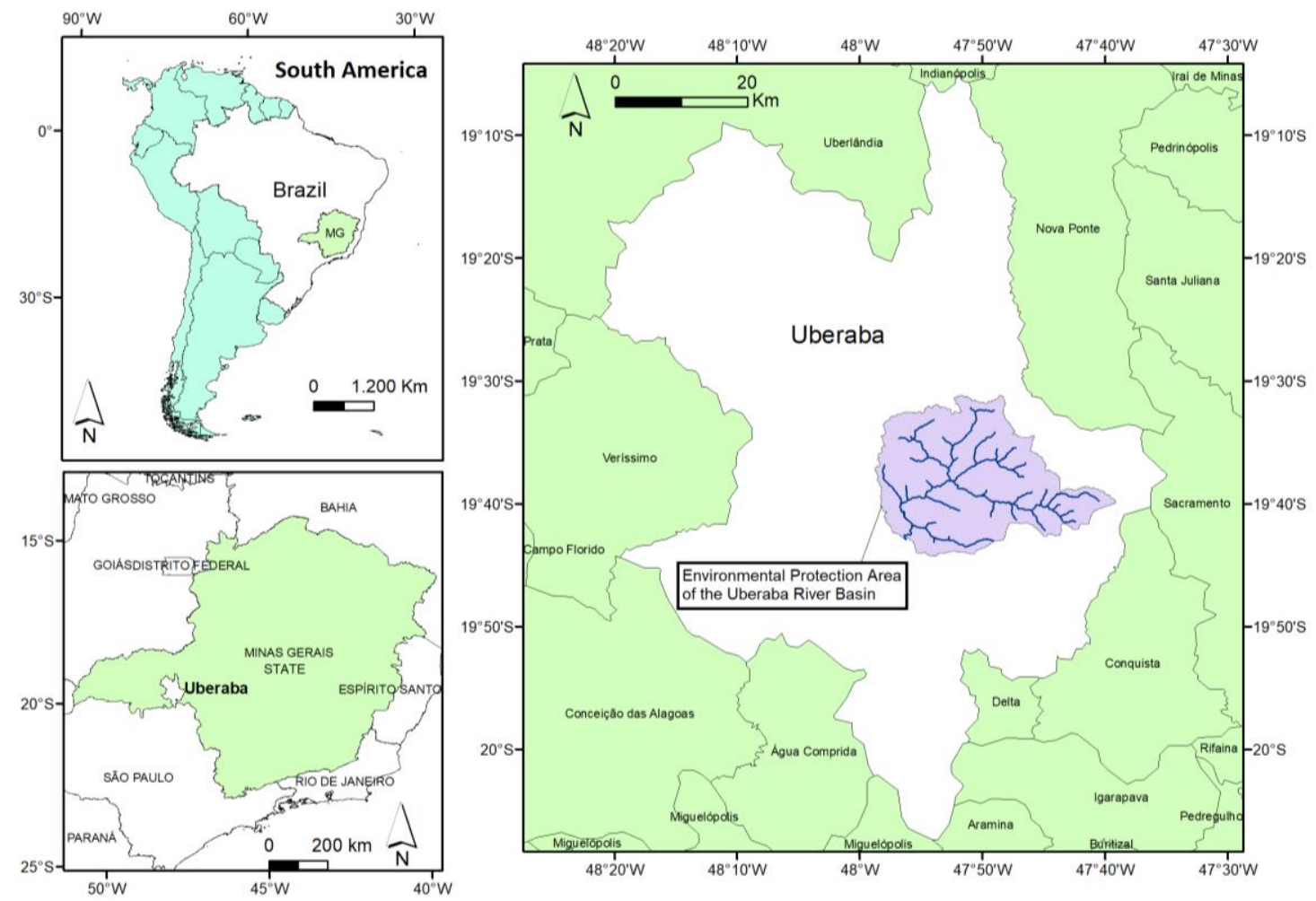

Figure 1. Geographic location of the EPA-URB.

The Uberaba River is part of the river basins Grande, Paraná and Plate (the second largest drainage basin in South America). It is valuable as a natural resource and for the supply of ecosystem services, especially in the economic aspects of agricultural activities and it is also the city's main water supply source (Uberaba, 2012). According to the Köppen climate classification, the rainfall regime is Aw, with rainy summer (October-March) and dry winter (May-September) and the average annual temperature in region is between $20^{\circ} \mathrm{C}$ and $22^{\circ} \mathrm{C}$ (Ribeiro et al., 2012).

\section{IPABH}


The EPA-URB (Figure 1) delimits the region of springs' protection and water recharge, located upstream of the city's water catchment point, with an area of approximately $530 \mathrm{~km}^{2}$, including $8 \%$ of urbanization (Uberaba, 2012). It was created by State Law Number 12.183 in 1999 and established limits and specific objectives through Municipal Law Number 9.892 in 2006 (Ribeiro et al., 2012).

The creation text of the EPA-URB includes reports about the emerging lithostratigraphic units throughout the CU influence area, as well as a comprehensive description of fossils discovered in these localities (Ribeiro, 2014). The soils present medium textures, with variations from clay to sandy soils, according to the Brazilian Soils Classification are classed as latosol of different fertility degrees, with dark-red latosol and dystrophic purple latosol predominating (Cruz et al., 2003).

\subsection{Conservation scenario by Multi-criteria Evaluation}

The proposed methodology involves the creation of an environmental conservation scenario with multicriteria evaluation tool support from IDRISI Selva software, adopting the necessary restrictions and factors (Miranda, 2010; Zhang et al., 2013; Costa et al., 2016; Valente et al., 2017). The main steps of the proposed multi-criteria evaluation are: factor standardization, hierarchy and aptitude map elaboration.

The only restriction used was the study area delimitation (binary image), as indicated in the law wording. It starts in the water catchment point for public supply and extends up to the divider limits of waters (ridgetop) in the upstream region. The drainage network, surface area and slope detection were extracted from the relief information of the Digital Elevation Model (DEM), obtained in the year 2015 by Advanced Spaceborne Thermal Emission and Reflection Radiometer (ASTER) and provided by the United States Geological Survey (USGS), in $30 \mathrm{~m}$ resolution (Costa et al., 2016).

\subsubsection{Factors standardization}

The factors have different data types (categorical or continuous) and therefore need to be standardized by means of reclassification or fuzzy logic application. Table 1 shows the factors according to the data type and corresponding standardization.

Table 1. Factors, data type and corresponding standardization factors.

\begin{tabular}{ccc}
\hline Factors & Data Type & Standardization Type \\
\hline Cover & Categorical & Reclassification \\
Soil & Categorical & Reclassification \\
Slope & Continuous & Fuzzy logic \\
DFRI & Continuous & Fuzzy logic \\
DFRO & Continuous & Fuzzy logic \\
DFRA & Continuous & Fuzzy logic \\
DFUL & Continuous & Fuzzy logic \\
\hline
\end{tabular}

Legend: DFRI $=$ Distance from rivers, DFRO $=$ Distance from roads, DFRA $=$ Distance from railway, DFUL $=$ Distance from urban limits.

This stage of the decision-making consists of the transformation of values of the original data into degrees of relevance ( 0 to 255 ), notably by means of fuzzy logic functions for continuous data, in this case the sigmoid monotonic function that determines the gradual change at the border among the phenomena, varying according to the adequacy levels in an interval (Miranda, 2010; Eastman, 2012; Zhang et al., 2013; Costa et al., 2016). 
The roads, railway and part of the urban limits belonging to the study area were scanned in cartographic scale of 1:15,000, on an GIS environmental. The conservation goals near the anthropic occupations are at higher disturbance, therefore, the distance of these areas increases the biodiversity protection level (Costa et al., 2016). Also included in the impact factors set considered important is the slope and distances from rivers, in a decreasing manner. This is because the higher the slope and the rivers' proximity, the greater must be the weight in relation to environmental conservation (Zhang et al., 2013)

The categorical type criteria are composed of classes, making it impossible the direct application of the fuzzy pertinence function. In this case, standardization occurs by operation of image value reclassification (0 to 255) (Oliveira et al., 2014). The relative importance of all factors was indicated and compensation was made among them, on account of their ecological function and the degradation processes arising from anthropic occupation with the literature support (Cruz et al., 2003). These were discussed by four technical specialists (Miranda, 2010; Eastman, 2012) in the areas of: environmental management; agricultural, civil and environmental engineering and their experience with sedimentometry, hydrology and geoprocessing.

The ecological function of the categorical data factors was considered, e.g., the role of native vegetation in controlling the input of sediments in water bodies and springs, especially when it comes to riparian forest, in addition to improving the local ecosystem by biological interactions (vegetation-soil-water) (Tundisi and Matsumura-Tundisi, 2014), and the role of hydromorphic soils in the water table recharge, and soils considered little anthropized or that suffered moderate weathering (Lepsch, 1993; EMBRAPA, 2013).

The degradation processes arising from anthropic occupation was considered, e.g., the critical changes of natural vegetation and the development of activities that negatively impact the environment (Zhang et al., 2013; Calijuri et al., 2015; Costa et al., 2016).

\subsubsection{Soil cover standardization}

Notably, the soil cover map was prepared based on the images' supervised classification procedure, using the Maximum Likelihood algorithm and accuracy was assured by the KIA statistical index (Poznanovic et al., 2014; Calijuri et al., 2015; Varga et al., 2015; Mishra and Rai, 2016). The image used was from Landsat 8 , in the bands of the Operational Land Imager (OLI) sensor, dated September 03rd 2017, provided by the Division of Image Generation (DGI) of the National Institute for Space Research (Instituto Nacional de Pesquisas Espaciais - INPE).

The classes of soil cover in the region and the respective standardization values, are:

(i) Anthropized area - value 0; basically in urban limits and exposed soil. The lowest standardization value, corresponding to critical changes of natural vegetation (Zhang et al., 2013; Costa et al., 2016);

(ii) agricultural area - value 80; the predominant agriculture under study is sugarcane, maize, soy and horticulture;

(iii) pastures - value 150; the pastures make the soil have a higher density than that which has not been cultivated, cattle-breeding leads to soil trampling and wear, where the management type can directly influence the soil compaction process, potentiating susceptibility to erosion (Uberaba, 2012), possibly responsible for the sedimentation formed and deposited in the riverbeds. A pasture without proper management can be a serious environmental problem, reflected in the case of degraded pastures (Dias-Filho, 2014). A study conducted in all of the Uberaba River Basin, by Valera et al. (2016), reported that since 1964 the landscape has changed significantly, and the native vegetation cover has been removed, being replaced by managed pastures used for livestock production; 
(iv) native vegetation - value 255; experts in ecology and nature conservation consider the vegetation as the most important criterion in the case of protected areas (Zhang et al., 2013). The plant cover is important in reducing erosion (Tundisi et al., 2003), determines the soil vulnerability, as well as the quali-quantitative increase of water, where the surface porosity and moisture absorption originated in the root system, depletes the water content in the soil by increasing the infiltration rate in the soil matrix (Biswas, 1976; Lepsch, 1993).

\subsubsection{Soil-type standardization}

The soil types (Table 2) map was obtained from Geoprocessing Laboratory database of the Uberaba University (UNIUBE). According to the Brazilian Soils Classification, the standardization values are laid down as follows:

Table 2. The EPA-URB soil types and respective standardization values.

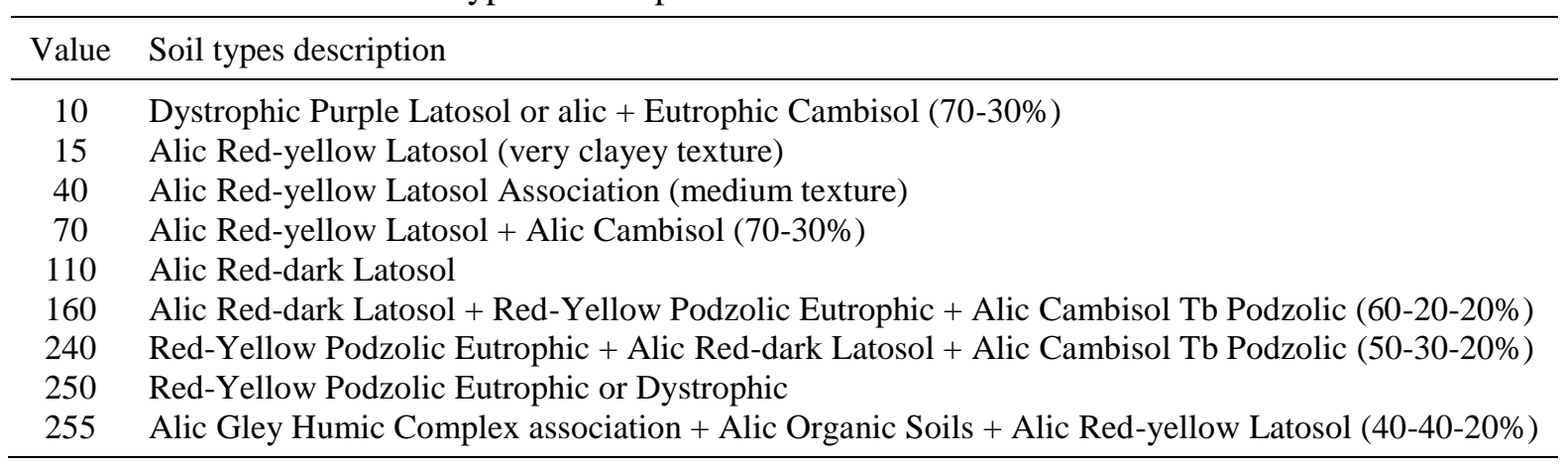

Source: Adapted from Cruz et al. (2003).

The standardization values were identified according to the main physical factors of soils and respective natural conservation characteristics together with the vulnerability (Costa et al., 2016; Vettorazzi and Valente, 2016). Scientific literature support was used for the texture, temperature/heat, aeration, infiltration capacity, water retention and structure (Lepsch, 1993). The properties considered as having influence on soil fragility are the flow, soluble salts, nutrient movement and oxygen in the soil, evapotranspiration, including the effects of dryness on the soil-plant-water system, and finally, reductions in sediment transport according to spacetime variability of soil properties (Scott, 2000).

The Latosol-type soil wase classified with low conservation values. It is considered an old soil that is stable and has been subjected to intense weathering. It is deep and most of the time impoverished in nutrients necessary to plants, under sparse vegetation (Lepsch, 1993).

The Podzolic-type soil was identified with high standardization values. It is from humid climate forest regions, with a well-developed profile, moderately impacted by weathering (EMBRAPA, 2013). It are in a shallower depth, and in situations of more rugged relief are found natural vegetation such as forests of broadleaf trees, and is considered very susceptible to water erosion (Lepsch, 1993).

The hydromorphic soils were standardized with the highest values. The Alic Humic Gley soil type is that which develops with the influence of high groundwater acting as areas of water table recharge, and the characteristics are dark, almost black, very soft and porous (Lepsch, 1993; EMBRAPA, 2013). In these regions, depressions are found that support the outcropping of groundwater, giving rise to some of the diffuse springs of Uberaba River, and in the surroundings are found differentiated geomorphological conformations where the "covoais" occur, which are clay mounds spread and colonized by small trees and shrubs (Uberaba, 2012). 


\subsection{Hierarchization of the factors}

The Analytical Hierarchy Process, widely cited in the specialized technique literature, was adopted (Oliveira et al., 2014) to compare the factors in pairs and then assign weights to each one (Miranda, 2010; Eastman, 2012; Costa et al., 2016; Valente et al., 2017). At the end of the comparison, the inconsistency in the process is verified through the Consistency Ratio (CR) (Saaty, 1987; Miranda, 2010). Once a tolerance value below 0.1 is obtained, it is possible to finalize the comparison and calculate the weights of each factor to be used in the MCE (Miranda, 2010; Vettorazzi and Valente, 2016).

\subsection{Aptitude map}

As a result, a map of aptitude to environmental conservation was obtained through the creation of a Weighted Linear Combination scenario (Miranda, 2010; Eastman, 2012; Costa et al., 2016; Valente et al., 2017). In this phase, the multiplication of each factor occurs (each pixel on the map) by its weight, then the sum of the results (Sartori et al., 2012).

\section{RESULTS AND DISCUSSION}

The EPA-URB soil cover map (Figure 2) demonstrated that the predominant activity is pasture, corresponding to $170 \mathrm{~km}^{2}$ and $34 \%$ of the study area. Candido et al. (2010), made the field recognition of the Uberaba River Basin vulnerability. The authors pioneered works with parameters of environmental degradation to group the methodologies found in spatial analysis and observed an extensive pasture area in the north of the basin (EPA-URB). Valera et al. (2016) conducted a field campaign to collect soil samples in the basin of the Uberaba River, aiming to verify the interference of soil use and occupation in the qualitative analysis of the samples. The study of Valera et al. (2016) also identify pasture as a predominant activity in the northern part of the Uberaba River Basin, showing that spatial analysis demonstrated in the present study and in the study of Candido et al. (2010) was satisfactory when compared to the field sampling.

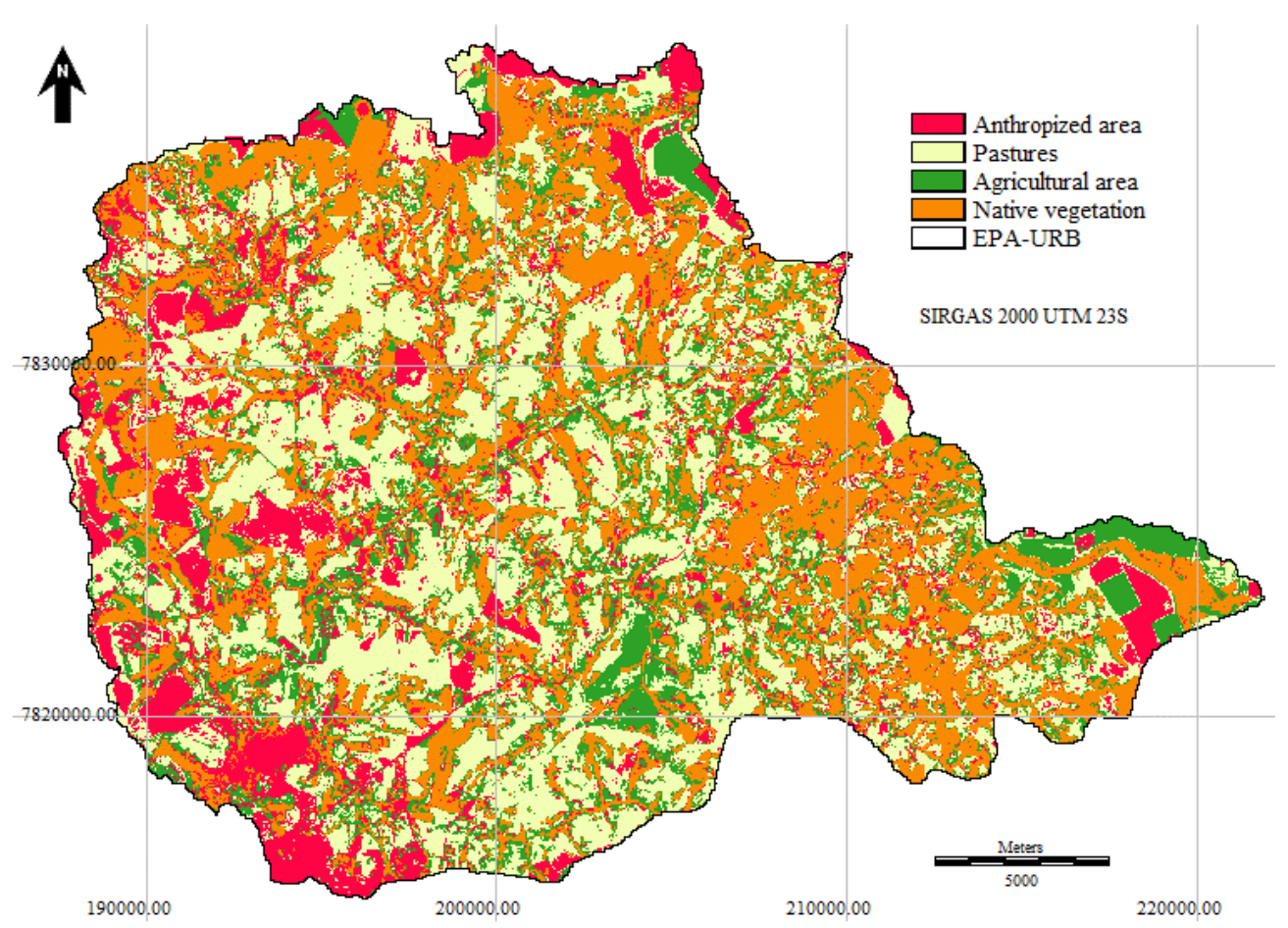

Figure 2. Land cover map of the EPA-URB, prepared based on the images supervised classification procedure. 
A study was carried out in a river basin located in Central-Eastern region of São Paulo state (Brazil) approximately $1,700 \mathrm{~km}^{2}$ in size, that is a strategic water source (Vettorazzi and Valente, 2016). The authors used the supervised classification to obtain the soil cover of the region and found that the human intervention was responsible for forest deforestation in parts. The predominant activities that occupy the region are pasture and sugarcane, occupying respectively $43 \%$ and $28 \%$ of the basin. In the present study, environmental changes were identified by pasture, agricultural (sugarcane), anthropized area and native vegetation, respectively, with 34\%, 18\%, 18\% and 30\% (approximately 94\% of thematic accuracy). The area studied by Vettorazzi and Valente (2016), is larger than that of the present study; however, the similarity found in both studies demonstrates that pasture and agriculture activities are responsible for deforestation in regions of the two states, among other activities. In addition, the classification technique used in both was the same, demonstrating it to be efficient for different regions.

The native vegetation areas which are still preserved (Figure 2) are arranged in scattered fragments, but the surroundings are taken by agriculture and anthropized area (exposed soil, probably in preparation for cultivation). This also was verified before, according Candido et al. (2010), by means of a typical example of soil use conflict in which the sugarcane crop advances to the spring areas of the Uberaba River (EPA-URB). Given this, the increase of the environmental changes caused by human occupation can occur if adequate management does not oversee land use. This condition reflects the need to apply decisive strategies to ensure the conservation of the area with the establishment of environmental policies aimed at the control of anthropic occupation, based on updated Management Plans (Brasil, 2000).

Table 3 shows that slope, soil types, soil cover and road distances were the most important factors for the results obtained in the environmental conservation map (Figure 3), with a 3\% inconsistency in the comparison process through the RC. Vettorazzi and Valente (2016) studied forest restoration for water conservation using the Analytical Hierarchy Process. In the elaboration of the influence factors, the following variables were incorporated: i) the incorrect association of land use, soil type and relief in land use adequacy factor; ii) soil type intrinsic characteristics in erodibility factor; and iii) factor of proximity to roads. These factors obtained high weights in the hierarchical process. Although the variables were incorporated in the factors elaborated by Vettorazzi and Valente (2016) and considered separately in the present study, both results obtained high weights for the slope, soil types, soil cover and roads distances. The associations among these criteria are fundamental to establish the susceptibility of erosive processes (Lepsch, 1993; Scott, 2000; Uberaba, 2012; Zhang et al., 2013), for environmental conservation and forest restoration, aiming at improving the quality and availability of water.

Table 3. Pared comparison of the factors and the respective weights obtained in the AHP.

\begin{tabular}{lcccccccc}
\hline Criteria & Cover & Soil & Slope & DFRI & DFRO & DFRA & DFUL & Weights \\
\hline Cover & 1 & & & & & & & 0,1946 \\
Soil & $1 / 3$ & 1 & & & & & & 0,1764 \\
Slope & $1 / 3$ & 1 & 1 & & & & & 0,2186 \\
DFRI & $1 / 5$ & $1 / 3$ & $1 / 3$ & 1 & & & & 0,0635 \\
DFRO & $1 / 3$ & $1 / 3$ & 3 & 5 & 1 & & & 0,1553 \\
DFRA & $1 / 5$ & $1 / 5$ & $1 / 3$ & 1 & $1 / 3$ & 1 & & 0,0451 \\
DFUL & $1 / 5$ & $1 / 5$ & $1 / 5$ & $1 / 5$ & $1 / 3$ & $1 / 3$ & 1 & 0,1465 \\
\hline
\end{tabular}

Legend: DFRI $=$ Distance from rivers, DFRO $=$ Distance from roads, DFRA $=$ Distance from railway, DFUL $=$ Distance from urban limits. 
Zhang et al. (2013) used a participatory process of environmental zoning in the study of protected areas in China. The authors observed that the Analytical Hierarchy Process resulted in greater weight factor for the isolated class of vegetation and environmental conservation targets. Similarly, in the present study the variable native vegetation is incorporated in the soil cover factor with the highest standardized importance in ratio to the other classes of soil cover. This demonstrates that the delimitation of the protected areas is a determinant factor for native vegetation conservation.

The area covered by native vegetation found in this study does not exceed $30 \%$ of the total area, which may influence the decline of the river water level in dry periods (Tundisi, 2005; Zhang et al., 2013; Calijuri et al., 2015;), and consequently affect the water supply of the municipality. The low river flow (water stress) promotes the need of system activation of transposition of another river in the region, and this increases the costs for the population (CODAU, 2017). The processes of environmental degradation that affect the availability and water quality of the water bodies are due to changes in vegetation and to the region's physical characteristics.

The environmental conservation map (Figure 3) shows the highest levels of environmental conservation priority in the region have been identified in the areas of springs and hydromorphic soils, where the "covoais" are located, which have great ecological importance for the hydrological cycle of the region (Uberaba, 2012). Therefore, it is recommended that the priority areas for conservation be incorporated in the Water Producer Program to provide technical support and payment for environmental services (ANA, 2012). Thus, the rural producers are encouraged to invest in conservation practices of water, soil and vegetation.

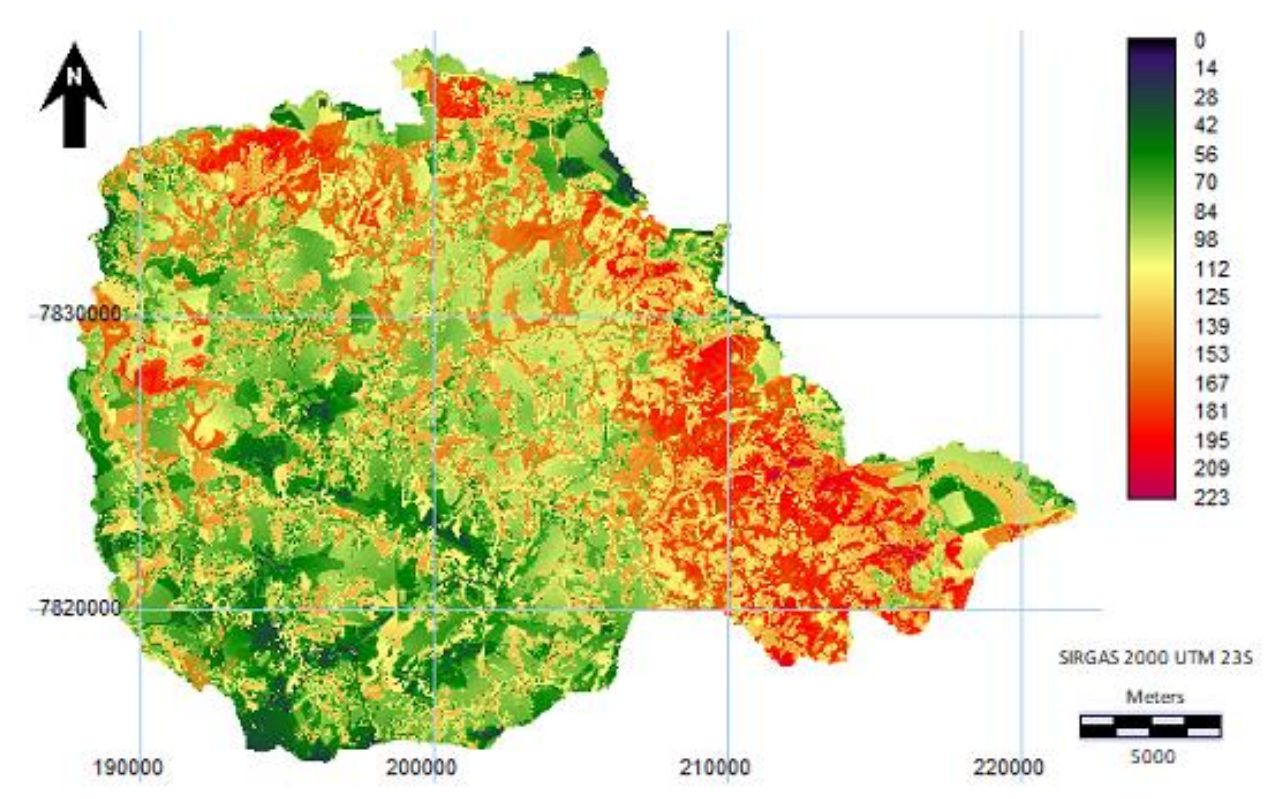

Figure 3. Environmental conservation levels of the EPA-URB, by MCE method.

The maximum value of conservation priority found was 223, probably due to the compensation among the established criteria. In general, the best results of conservation adequacy were found in the proximity of the higher values of relief, slope, occupation by native vegetation and presence of hydromorphic soils. In the study by Ioana-Toroimac et al. (2017), priority rivers were identified for hydromorphological restoration in Romania based on multicriteria evaluation. The factors were designed to recognize human pressures, channel changes and fluvial functionality. In the present study, the values resulted from low- to medium levels of conservation in general, even in the regions closer to the water bodies. Therefore, the factors elaborated by Ioana-Toroimac et al. (2017), if adapted to the factors considered in the present 
study, can present considerable levels of environmental conservation near the water bodies. This is a suggestion for future works.

Areas with high slopes are located in the northern regions. This leads to the potential of surface runoff generated by heavy rains, favoring the formation of trench erosions at some points (Lepsch, 1993; Scott, 2000; Uberaba, 2012; Zhang et al., 2013). Candido et al. (2010), in a study in the same basin as the present study observed that the anthropic occupation reached areas protected by law. The authors identified a moderate to severe level of environmental degradation in EPA-URB, evidencing signs of exhaustion of natural resources. The study of Candido et al. (2010) and the present study suggest that soil degradation should be continuously monitored by evaluating environmental conservation and anthropic occupation.

\section{CONCLUSIONS}

In this study, a map was developed containing the environmental conservation levels considering environmental factors and their changes due to human activities in the EPA-URB. Areas with higher priority were identified in plots of native vegetation, floodplains, hydromorphic soils, water recharge sites, high slopes, "covais" and springs. These are areas of extreme importance for the maintenance of water resources and their conservation is a priority for local demand for water supply.

It is concluded that the established criteria, the standardization and the obtaining of weights for the multi-criteria evaluation, allowed a consistent analysis in relation to the levels of priority to environmental conservation. In addition, the generated map can help in decision making for the adequate management of the region's sustainability, by the managers in the management plan elaboration.

The proposed methodology (multi-criteria evaluation) can be applied if specialists are available, both in the technical area of hydrology, sedimentometry and environmental management, as well as in the treatment of spatial information. This tool is used to elaborate adequate maps and to identify critical areas and zoning.

\section{REFERENCES}

AGÊNCIA NACIONAL DE ÁGUAS - ANA (Brasil). Manual operativo do programa produtor de água. 2. ed. Brasília, 2012. 92p.

BISWAS, A. K. Water Resources: Environmental Planning, Management, and Development.New York: McGraw-Hill, 1976. 737p.

BRASIL. Lei $n^{\circ}$ 9.985, de 18 de julho de 2000. Regulamenta o art. 225, $\S 1^{\circ}$, incisos I, II, III e VII da Constituição Federal, institui o Sistema Nacional de Unidades de Conservação da Natureza e dá outras providências. Diário Oficial [da] União: seção 1, Brasília, DF, jul. 2000 .

CALIJURI, M. L.; CASTRO, J. de S.; COSTA, L. S.; ASSEMANY, P. P.; ALVES, J. E. M. Impact of land use/land cover changes on water quality and hydrological behavior of an agricultural subwatershed. Environmental Earth Sciences, v. 74, n. 6, p. 5373-5382, 2015. https://doi.org/10.1007/s12665-015-4550-0

CANDIDO, H. G.; GALBIATTI, J. A.; PISSARRA, T. C. T.; MARTINS FILHO, M. V. Degradação ambiental da bacia hidrográfica do rio Uberaba: uma abordagem metodológica. Engenharia Agrícola, Jaboticabal, v. 30, n. 1, p. 179-192, fev. 2010. http://dx.doi.org/10.1590/S0100-69162010000100019 
CENTRO OPERACIONAL DE DESENVOLVIMENTO E SANEAMENTO DE UBERABA - CODAU. Abastecimento Rio Uberaba. 2017. Available in: http://www.codau.com.br/noticiaDetalhe.php?codigo=5000040. Access on: 20 Feb. 2018.

COSTA, T. de O.; ASSIS, L. R. de; CALIJURI, M. L.; ASSEMANY, P. P.; LIMA, G. S. Defining Priority Zones for Conservation and Ecotourism in a Protected Area. Revista Árvore, v. 40, n. 5, p. 769-779, 2016. http://dx.doi.org/10.1590/010067622016000500001

CRUZ, L. B. S.; PATERNIANI, J. E. S.; CARVALHO, R. M. B. Caracterização e manejo sustentável do solo na bacia do Rio Uberaba (MG). Caminhos de Geografia, v. 4, n. 9, p. 31-49, 2003.

DIAS-FILHO, M. B. Diagnóstico das Pastagens no Brasil. Belém, PA: Embrapa Amazônia Oriental, 2014. 37p.

EASTMAN, J. R. IDRISI Selva Manual. 17. ed. Worcester: IDRISI Production, 2012. 322p.

EMPRESA BRASILEIRA DE PESQUISA AGROPECUÁRIA - EMBRAPA. Sistema brasileiro de classificação de solos. 3. ed. Brasília, DF: Embrapa Informação Tecnológica, 2013. 342p.

FRANCO, R. A. M.; HERNANDEZ, F. B. T.; MORAES, J. F. L. DE. O uso da análise multicritério para a definição de áreas prioritárias a restauração de Área de Preservação Permanente (APP), no noroeste paulista. In: SIMPÓSIO BRASILEIRO DE SENSORIAMENTO REMOTO, 16., abril 2013, Foz do Iguaçu, PR. Anais [...]. São José dos Campos: INPE, 2013. p. 3366-3373.

INSTITUTO BRASILEIRO DE GEOGRAFIA E ESTATÍSTICA - IBGE. Censo demográfico: Panorama - População (Uberaba). 2017. Available in: http://cidades.ibge.gov.br/xtras/perfil.php?codmun=317010. Access on: 20 Feb. 2018.

IOANA-TOROIMAC, G.; ZAHARIA, L.; MINEA, G.; MOROȘANU, G.A. Using a multicriteria analysis to identify rivers with hydromorphological restoration priority: Braided rivers in the south-eastern Subcarpathians (Romania). Science of The Total $\begin{array}{llllll}\text { Environment, } & \text { v. } & 599-600, & \text { p. } & 700-709,\end{array}$ https://doi.org/10.1016/j.scitotenv.2017.04.209

LEPSCH, I. F. Solos: formação e conservação. 5. ed. São Paulo: Prisma, 1993. 157p.

MIRANDA, J. I. Fundamentos de sistemas de informações geográficas. 2. ed. Brasília: Embrapa Informação Tecnológica, 2010. 433p.

MISHRA, V. N.; RAI, P. K. A remote sensing aided multi-layer perceptron-Markov chain analysis for land use and land cover change prediction in Patna district (Bihar), India. Arabian Journal of Geosciences, v. 9, n. 4, p. 249, 2016. https://doi.org/10.1007/s12517-015-2138-3

MONTGOMERY, B.; DRAGIĆEVIĆ, S.; DUJMOVIĆ, J.; SCHMIDT, M. A GIS-based Logic Scoring of Preference method for evaluation of land capability and suitability for agriculture. Computers and Electronics in Agriculture, v. 124, p. 340-353, 2016. https://doi.org/10.1016/j.compag.2016.04.013 
OLIVEIRA, F. B. de; OLIVEIRA, C. H. R. de; LIMA, J. S. de S.; MIRANDA, M. R.; RIBEIRO FILHO, R. B.; TURBAY, E. R. M. G. et al. Definição de áreas prioritárias ao uso público no parque estadual da Cachoeira da Fumaça - ES, utilizando geoprocessamento. Revista Árvore, v. 38, n. 6, p. 1027-1036, 2014. http://dx.doi.org/10.1590/S010067622014000600007

POZNANOVIC, A. J.; FALACIOSO, M. J.; MACLEAN, A. L.; SMITH. A. M. S; EVANS, J. S. An Accuracy Assessment of Tree Detection Algorithms in Juniper Woodlands. Photogrammetric Engineering \& Remote Sensing, v. 80, n. 5, p. 627-637, 2014. https://doi.org/10.14358/PERS.80.7.627

RIBEIRO, L. C. B.; TREVISOL, A.; CARVALHO, I. de S.; MACEDO NETO, F.; MARTINS, L. A. et al. Geoparque Uberaba - Terra dos Dinossauros do Brasil (MG): proposta. Uberaba, MG: CPRM, 2012. p. 583-616.

RIBEIRO, L. C. B. Geoparque Uberaba - Terra dos Dinossauros do Brasil. 2014. 124p. Thesis (Doctorate in Sciences, Geology) - Instituto de Geociências, Universidade Federal de Rio de Janeiro, Rio de Janeiro, 2014.

SAATY, R. W. The Analytic Hierarchy Process: What It Is and How It Is Used. Mathematical Modelling, v. 9, n. 3, p. 161-176, 1987. https://doi.org/10.1016/0270-0255(87)90473-8

SARTORI, A. A. da C.; SILVA, R. F. B. da; ZIMBACK, C. R. L. Weighted linear combination of a GIS environment in the definition of priority areas for connectivity among forest fragments. Revista Árvore, v. 36, n. 6, p. 1079-1090, dez. 2012. http://dx.doi.org/10.1590/S0100-67622012000600009

SCOTT, H. D. Soil Physics: Agricultural and Environmental Applications. 1. ed. Iowa: Iowa State University Press, 2000. 421p.

TUNDISI, J. G. Água no século XXI: enfrentando a escassez. 2. ed. São Carlos: Rima, 2005. $256 \mathrm{p}$.

TUNDISI, J. G.; MATSUMURA-TUNDISI, T. The ecology of UHE Carlos Botelho (LoboBroa Reservoir) and its watershed, São Paulo, Brazil. Freshwater Reviews, Washington, v. 6, n. 2, p. 75-91, 2014. https://doi.org/10.1608/FRJ-6.2.727

TUNDISI, J. G.; MATSUMURA-TUNDISI, T.; RODRIGUES, S. L. Gerenciamento e Recuperação das Bacias Hidrográficas dos Rios Itaquerí e do Lobo e da UHE Carlos Botelho (Lobo-Broa). São Carlos: IEE/IIEGA, 2003. 55p.

UBERABA. Secretaria de Meio Ambiente e Turismo. Plano de manejo emergencial: área de proteção ambiental municipal do rio Uberaba. Uberaba: Centro Operacional de Desenvolvimento e Saneamento de Uberaba, 2012. 153p.

VALENTE, R. A.; PETEAN, F. C. de S.; VETTORAZZI, C. A. Multicriteria Decision Analysis for Prioritizing Areas for Forest Restoration. CERNE, v. 23, n. 1, p. 53-60, 2017. http://dx.doi.org/10.1590/01047760201723012258

VALERA, C. A.; VALLE JUNIOR, R. F.; VARANDAS, S. G. P.; SANCHES FERNANDES, L. F.; PACHECO, F. A. L. The role of environmental land use conflicts in soil fertility: A study on the Uberaba River basin, Brazil. Science of The Total Environmental, v. 562, p. 463-473, 2016. https://doi.org/10.1016/j.scitotenv.2016.04.046 
VARGA, K.; SZABÓ, S.; SZABÓ, G.; DÉVAI, G.; TÓTHMÉRÉSZ, B. Improved land cover mapping using aerial photographs and satellite images. Open Geoscience, v. 7, p. 15-26, 2015. https://doi.org/10.1515/geo-2015-0002

VETTORAZZI, C. A.; VALENTE, R. A. Priority areas for forest restoration aiming at the conservation of water resources. Ecological Engineering, v. 94, p. 255-267, 2016. https://doi.org/10.1016/j.ecoleng.2016.05.069

ZHANG, Z.; SHERMAN, R.; YANG, Z.; WU, R. WENLI, W. YIN, M. YANG, G.; OU, X. Integrating a participatory process with a GIS-based multi-criteria decision analysis for protected area zoning in China. Journal for Nature Conservation, v. 21, n. 4, p. 225240, 2013. https://doi.org/10.1016/j.jnc.2012.12.006

ZHANG, X.; WU, B.; LING, F.; ZENG, Y.; YAN, N.; YUAN, C. Identification of priority areas for controlling soil erosion. CATENA, v. 83, n. 1, p. 76-86, 15 out. 2010. https://doi.org/10.1016/j.catena.2010.06.012 